\title{
The Impact of Leachate on the Quality of Surface and Groundwater and Proposal of Measures for Pollution Remediation
}

\author{
Irma Dervišević ${ }^{*}$, Jelena Đokićn ${ }^{1}$, Nataša Elezovićn ${ }^{1}$, Gordana Milentijević ${ }^{1}$, \\ Vladan Ćosovićc ${ }^{2}$ Almin Dervišević ${ }^{3}$ \\ ${ }^{1}$ University of Prishtina, Faculty of Technical Sciences, Kosovska Mitrovica, Serbia \\ ${ }^{2}$ University of Belgrade, Institute of Chemistry, Technology and Metallurgy, Belgrade, Serbia \\ ${ }^{3}$ State University of New Pazar, Department of Chemical and Technological Science, New Pazar, Serbia \\ Email: "irma.dervisevic@pr.ac.rs, drvisevicirma@hotmail.com
}

Received 16 March 2016; accepted 19 April 2016; published 22 April 2016

Copyright (C) 2016 by authors and Scientific Research Publishing Inc.

This work is licensed under the Creative Commons Attribution International License (CC BY). http://creativecommons.org/licenses/by/4.0/

\section{(c) (i) Open Access}

\begin{abstract}
Direct discharge of municipal and industrial waste waters and leachate (originating from the illegal landfills) into recipients without prior purification is unfortunately very common practice in the region of northern Kosovo. In addition, irresponsible and incorrect selection of sites for industrial and municipal dumps, which are often located in vicinity or on actual river banks, contributes significantly to environmental pollution. Analysis of the leachate from such sites was done by direct sampling and by using TCLP (Toxicity Characteristic Leashing Procedures) method. Based on the analysis of physicochemical parameters of the filtrated water from the sites Žitkovac, Grabovac and Balaban and analysis of the samples of surface water and groundwater from the site Grabovac, possible steps for removal and reduction of the existing pollution were proposed. Potential permanent solution in form of purification of municipal and industrial waste waters as well as leachate from illegal landfills was suggested. The potential implementation of remediation with a unified system for water purification, by using Membrane Bio Reactor (MBR), which includes the process of stabilization/solidification of a residual sludge, would have as an end product a neutral powder material completely safe for the environment, suitable for a variety of applications.
\end{abstract}

\section{Keywords}

Wastewater Treatment, Membrane Bio-Reactor, Solidification, Neutral, Environment

\footnotetext{
${ }^{*}$ Corresponding author.
} 


\section{Introduction}

The attitude of a society towards the environment is a good indicator of its awareness and a level of development. Scattered, illegal landfills represent one of the largest pollutants of surface and ground water, soil and atmosphere. In the region of northern Kosovo, majority of legal and illegal dumps are located on the alluvial deposits of rivers, near villages, and directly affect the spread of pollution. The environment is additionally threatened by a large number of industrial landfills, which originate from the process of Mining-MetallurgicalChemical Plant "Trepča"-RMHK Trepča. This region has the largest lead-zinc ore deposits in Kosovo and among the largest in Europe, which have been exploited with interruptions from XIII-XXI century. RMHK Trepča lead and zinc plant was established by nationalization of property after the Second World War and it is characterized by inappropriate choice of landfill sites (mostly located on the banks of the rivers Sitnica and Ibar) and a lack of appropriate collectors for wastewater treatment. Heavy metals are known to have adverse effects on the environment and human health [1]. Highly reactive and often toxic at low concentrations, they may enter soils and groundwater, bioaccumulation in food webs, and adversely affect biota, [2] [3], also, they can cause irreversible changes in the body especially in the central nervous system [4]. High levels of heavy elements such as lead $(\mathrm{Pb})$, zinc $(\mathrm{Zn})$, copper $(\mathrm{Cu})$, arsenic $(\mathrm{As})$, cadmium $(\mathrm{Cd})$ and antimony $(\mathrm{Sb})$ are usually found in surface soils of areas affected by mining and basic metallurgical or smelting activities, metal factories, traffic emissions and intense agricultural practices [5]-[8]. Soil contamination by heavy elements therefore represents a worldwide environmental concern mainly because these elements can be transferred to the hydrosphere and biosphere, thereby posing a hazard to human health. Consequently the mobility and bioavailability of heavy elements in soil play an important role in the uptake of these contaminants by vegetation and animals [9]. Furthermore, filtrate water, atmospheric origin water constituent, as well as the water that is produced in the body of the landfill, form a medium in which, in the process of decomposition and degradation pollutants are released and thus define the quality of the landfill leachate (filtrate water from the landfill). In addition to the physicochemical processes that take place and external environmental conditions, composition of the landfill leachate is influenced by a host of other variable factors such as the composition of the waste, the thickness of the landfill body, fluid migration path and the possibility of intermediate layers that adsorb or absorb and minimize pollution. Formed filtrate from informal, illegal dumps is in direct contact with surface water and groundwater [10] [11], except in the case of sanitary landfills, whose standards are in accordance with the Law on Waste Management, the Law on Environmental Protection and standards and the EU regulations on waste management. Pollution of soil, surface and ground water [12] [13] may directly and indirectly enable organic and inorganic polluting substances and heavy metals to enter into the food chain [14] [15] and seriously endanger the health of people [16] [17]. The chemical composition of the leachate reflects the sum of all processes occurring within the waste body, affecting especially the organic fraction [18]-[20]. Degradation processes of municipal landfills can be globally divided into four phases. The first three phases last for a relatively short period, 180 to 200 days. In the fourth, methane phase, landfill matures i.e. comes to balancing anaerobic process in which a relatively equal amounts of $\mathrm{CO}_{2}$ and $\mathrm{CH}_{4}$ are released [21]-[23]. The objective of this study was to evaluate the effects of pollutants from the leachate of informal dumps on surface and ground waters in their surroundings and in view of the complexity of the problem (due to a permanent emission of the pollutants from the leachate of illegal waste landfills as well as from the industrial waste deposits, that impact the quality of surface and ground waters) to propose possible steps for reduction of the existing pollution and prevention of future pollution.

\section{Materials and Methods}

\subsection{Study Area}

Samples of the leachate originating from the municipal waste deposits were analyzed along with samples of surface and ground waters. The leachate samples were taken at the end of February 2014, while the surface and ground water samples were taken in intervals: April, 2013, September, 2013, and February 2014. In order to determine leachate characteristics with different stage of decomposition, the samples were taken from different locations and from different vertical column depth. Sampling information is given in Table 1 and in Figures 1-3, together with the maps with marked locations from where the samples were taken.

\subsection{The Leachate and Water Sampling}

The leachate water samples from the location Balaban intended for the basic and detailed physical and chemical 


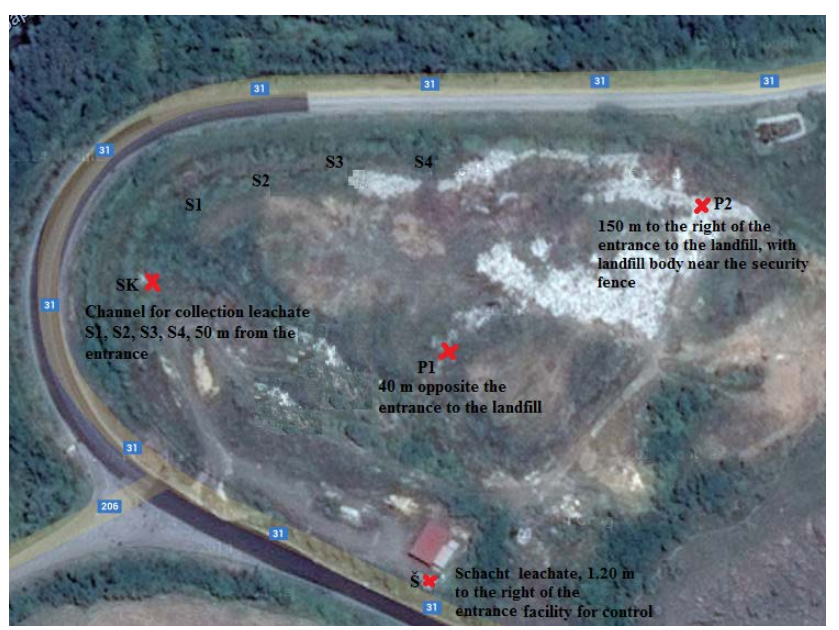

Figure 1. Map of site Balaban landfill with marked sampling points [24].

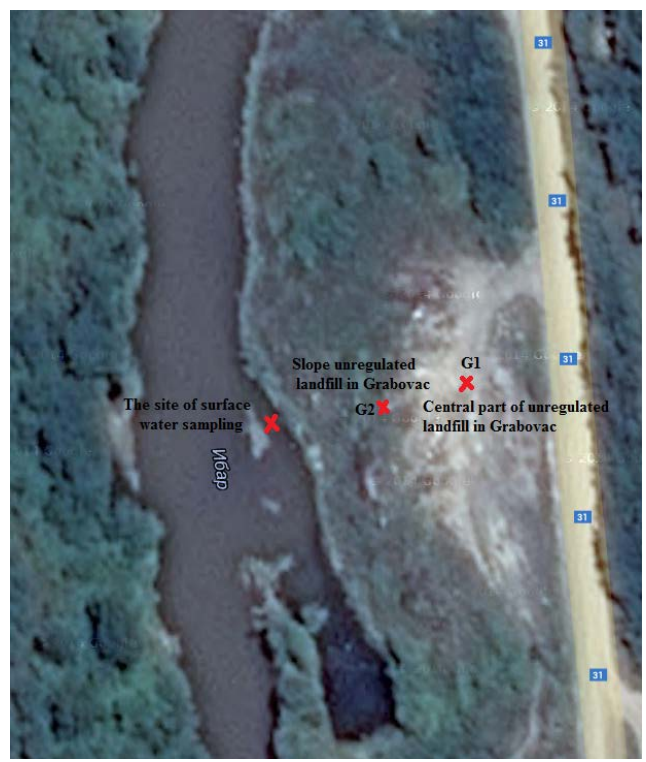

Figure 2. Map of site Grabovac, the informal landfill with marked sampling points [24].

Table 1. Points of sampling leachate to sites of selected landfills.

\begin{tabular}{|c|c|c|c|}
\hline Locality & Sampling points & Description of sampling & Depth \\
\hline \multirow{4}{*}{ Landfill Balaban } & $\begin{array}{l}\text { Monitoring wells } \\
\text { (Piezometer (P1)) }\end{array}$ & $40 \mathrm{~m}$ opposite the entrance to the landfill & $3 \mathrm{~m}$ \\
\hline & $\begin{array}{l}\text { Monitoring wells } \\
\text { (Piezometer (P2)) }\end{array}$ & $\begin{array}{l}150 \mathrm{~m} \text { to the right of the entrance to the landfill, } \\
\text { with landfill body near the security fence }\end{array}$ & $3 \mathrm{~m}$ \\
\hline & Schacht (ك̌3) & $\begin{array}{l}\text { Schacht leachate, } 1.20 \mathrm{~m} \text { to the right of the } \\
\text { entrance facility for control }\end{array}$ & $3 \mathrm{~m}$ \\
\hline & Sewer (SK4) & $\begin{array}{l}\text { Channel for collection leachate S1, S2, S3, S4, } 50 \mathrm{~m} \\
\text { from the entrance }\end{array}$ & $4 \mathrm{~m}$ \\
\hline \multirow{2}{*}{$\begin{array}{l}\text { Unregulated landfill } \\
\text { in Grabovac on the } \\
\text { bank of river Ibar }\end{array}$} & The sample (G1) & Central part of unregulated landfill in Grabovac & $1 \mathrm{~m}$ \\
\hline & The sample (G2) & $\begin{array}{l}\text { Slope unregulated landfill in Grabovac on the } \\
\text { right bank of the river Ibar }\end{array}$ & $1.5 \mathrm{~m}$ \\
\hline \multirow{2}{*}{$\begin{array}{l}\text { Unregulated landfill in } \\
\text { Žitkovac }\end{array}$} & The sample (Ž1) & The Northeast part of the landfill ( $3 \mathrm{~m}$ from the edge) & $2 \mathrm{~m}$ \\
\hline & The sample (Ž2) & The Southeastern part of the landfill ( $3 \mathrm{~m}$ from the edge) & $2 \mathrm{~m}$ \\
\hline
\end{tabular}




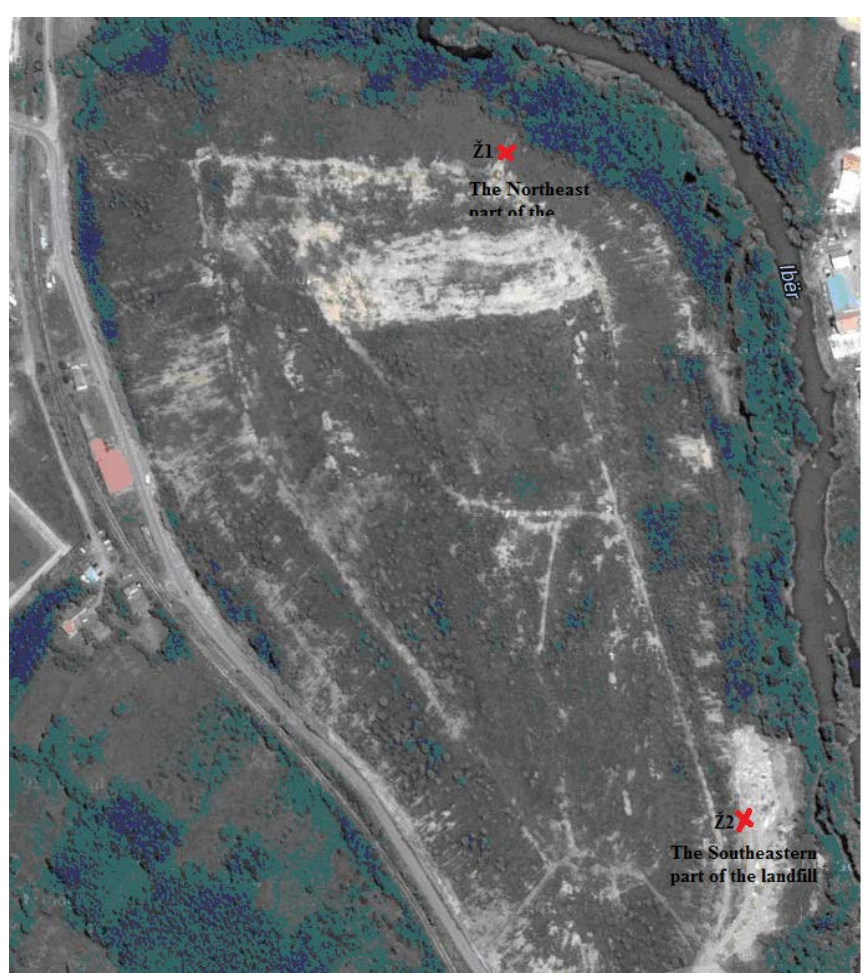

Figure 3. Map of site Žitkovac, the informal landfill with marked sampling points [24]. Note: Satellite images landfills shown in Figures 1-3. (are downloaded from the website www.google.rs/maps) only show sampling points, because they are old and do not show the current enormous amount of waste in the studied sites.

analysis, were collected in the plastic bottles of $2 \mathrm{dm}^{3}$, while the wastes from illegal landfills on the locations Grabovac and Žitkovac were collected into the plastic bags in order to simulate washout wastes and leaching waters in the laboratory (in regard to TCLP method-Toxicity Characteristic Leashing Procedures) [25]. All of the samples, after collection, were marked in according to the procedure of sampling and were stored in the refrigerator at about $4^{\circ} \mathrm{C}$ until the sample preparation for the analysis. Figure 4 shows the sampling of leachate at the landfill Balaban.

For the purpose of testing the leachate from the illegal dumps the samples were taken from dumps in Grabovac and Žitkovac, and TCLP method was applied. Nowadays there are a number of methods that can be used to simulate the process of leaching of waste in a landfill or in the environment in order to assess the content of pollutants, or to determine the characteristics of the leachate in contact with the test material. Depending on the alkalinity and buffering capacity of waste two different extraction solutions were used in the applied TCLP method: solution 1 and 2 with $\mathrm{pH}$ of 4.92 and 2.88, respectively. In the first step, $\mathrm{pH}$ levels of the samples were determined in order to select the appropriate extraction solution for leaching. The solution was mixed together with $5 \mathrm{~g}$ of crushed and homogenized waste sample (with diameter less than $1 \mathrm{~mm}$ ) and then mixed for 5 minutes with $96.5 \mathrm{~cm}^{3}$ of distilled water. In line with the US procedure EPA [25], for the $\mathrm{pH}$ of the obtained sample solution lower than 5, extraction solution 1 was used for leaching whereas in case of the $\mathrm{pH}$ higher than 5 , extraction solution 2 was used. The samples were crushed and sieved, so for the analysis only fractions smaller than $9.5 \mathrm{~mm}$ were used. After that, the extraction solution was added according to the procedure [26] at a 1:20 mix of sample and solvent. For example, in this particular case a TCLP jug contain $100 \mathrm{~g}$ of sample and added solution to $2 \mathrm{dm}^{3}$ (liter); (prepared of solution: Extraction fluid 1: Add $5.7 \mathrm{ml}$ glacial $\mathrm{CH}_{3} \mathrm{CH}_{2} \mathrm{OOH}$ to $500 \mathrm{ml}$ of reagent water, add $64.3 \mathrm{ml}$ of $1 \mathrm{~N} \mathrm{NaOH}$, and dilute to a volume of $1 \mathrm{dm}^{3}$ (liter). When correctly prepared, the $\mathrm{pH}$ of this fluid will be $4.92+0.05$. Extraction fluid 2: Dilute $5.7 \mathrm{ml}$ glacial $\mathrm{CH}_{3} \mathrm{CH}_{2} \mathrm{OOH}$ with reagent water to a volume of $1 \mathrm{dm}^{3}$ (liter). When correctly prepared, the $\mathrm{pH}$ of this fluid will be $2.88+0.05$ ). The leachate mixture is sealed in extraction vessel for general analytes, and tumbled for 18 hours to simulate an extended leaching time in the ground. The solution was subsequently separated by filtration through a glass fiber filter (pore size 0.7 microns) under vacuum (suction) and then analyzed. 


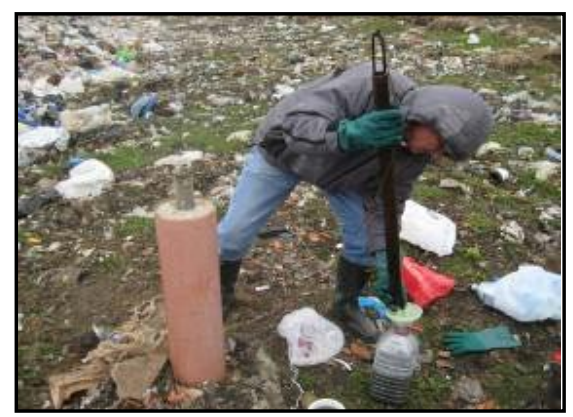

P1

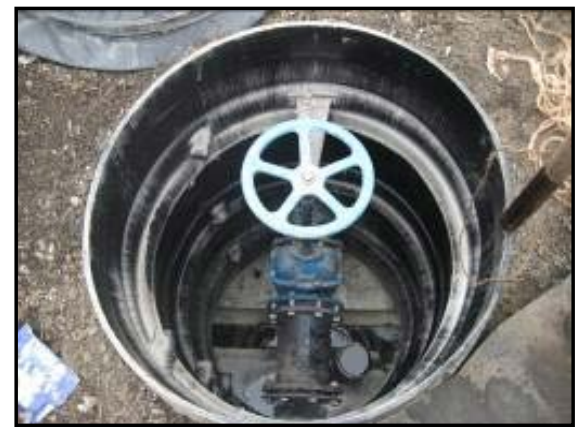

$\breve{\mathrm{S}} 3$

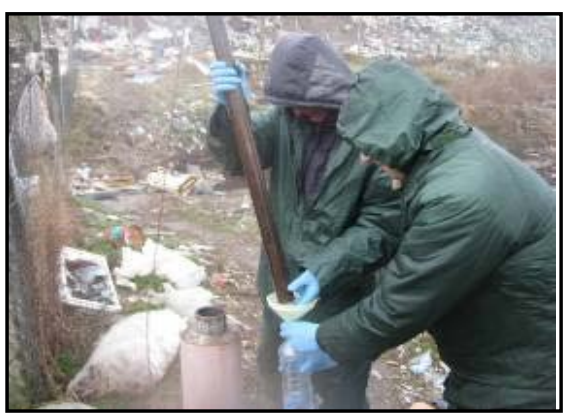

P2

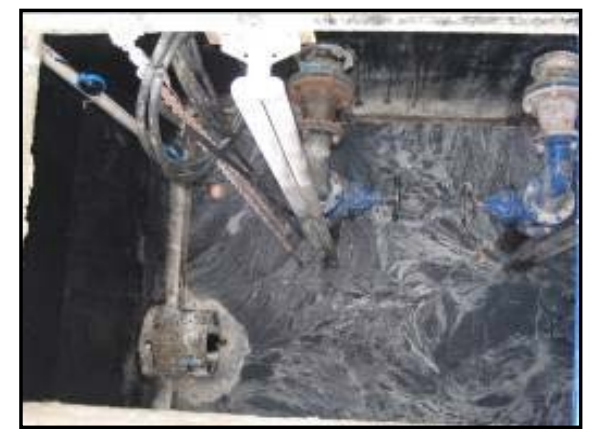

SK4

Figure 4. Sampling of leachate at the landfill Balaban.

\subsection{Chemical Analysis}

Qualitative and quantitative analysis of physical-chemical parameters of the leachate and waters was carried out using multiparameter equipment for water sampling Multi 340i Wissenschaftlich-technische Werkstatten GmbH (for the measurement and the determination of several parameters: $\mathrm{pH} /$ oxygen, conductivity and temperature), Dissolved oxygen (DO), biochemical oxygen demand (BOD) were measured with Winkler aside method. Most of parameters leachate are expressed in milligrams per cubic decimeter $\left(\mathrm{m} \mathrm{g} / \mathrm{dm}^{3}\right)$, except $\mathrm{pH}, \mathrm{EC}(\mu \mathrm{S} / \mathrm{cm})$ and temperature $\left({ }^{\circ} \mathrm{C}\right)$. As soon as the samples of leachate and water were brought to the laboratory they were preserved with $1 \mathrm{ml}$ of concentrated nitric acid $\left(\mathrm{HNO}_{3}\right)$, filtered and stored in dark at an ambient temperature until microwave acid digestion following [27]. The digestion of $50 \mathrm{ml}$ was performed with 4 - $5 \mathrm{ml} \mathrm{HNO}_{3} 65 \%$ and 1 $\mathrm{ml} \mathrm{HCl} \mathrm{35 \%}$. Total metal samples were filtered through $0.45 \mu \mathrm{m}$ nylon filters after digestion. The concentrations of $\mathrm{Cr}, \mathrm{Ni}, \mathrm{Pb}, \mathrm{Cd}, \mathrm{Zn}, \mathrm{Hg}, \mathrm{Fe}$, and $\mathrm{Cu}$ were measured using inductively coupled plasma-optical emission spectrometry (ICP-OES Optima 2100 DV) in accordance with the standard method [28] and are expressed in nanograms per cubic decimeter $\left(\mu \mathrm{g} / \mathrm{dm}^{3}\right)$. Three independent replicates were performed for each sample and blanks were measured in parallel for each set of analyses using the same procedure. All reagents used in this work were analytical or HPLC grade and used without any further purification. Indicator of the loading with biodegradable organic water pollutants or water activity is expressed as an Index of Phosphates Activity (IPA— $\left(\mu \mathrm{mol} / \mathrm{s} / \mathrm{dm}^{3}\right)$ p $\mathrm{NP}, 30^{\circ} \mathrm{C}$ ). Based on this index the water quality is characterized according to the categorization [29] [30].

\section{Results and Discussion}

\subsection{The Impact of Leachate on the Quality of Surface and Groundwater}

General and detailed analysis of physical and chemical properties of the leachate, surface and ground waters included: determination of the dissolved oxygen concentration, hydrogen ions concentration ( $\mathrm{pH}$ values), electrical conductivity and hardness of water, as well as determination of parameters of the organic pollution such as chemical oxygen demand and biological oxygen demand in five days $\left(\mathrm{BOD}_{5}\right)$. The results of the basic and detailed physical and chemical analysis of the samples of landfill leachate Balaban are given in Table 2.

Based on the data presented in the Table 2, regarding the quality of the leachate from the landfill Balaban, it can be concluded it is extremely polluted and cannot be discharged into the recipient without prior treatment. 
Table 2. Physicochemical parameters of the leachate from the landfill Balaban.

\begin{tabular}{|c|c|c|c|c|c|c|c|}
\hline \multirow{2}{*}{ Nr. } & \multirow{2}{*}{ The investigated parameters } & \multirow{2}{*}{$\begin{array}{l}\text { Identification } \\
\text { methods }\end{array}$} & \multirow{2}{*}{$\begin{array}{l}\text { unit of } \\
\text { issue }\end{array}$} & \multicolumn{4}{|c|}{ Monitoring wells of leachate } \\
\hline & & & & P1 & P2 & Š3 & SK4 \\
\hline 1. & The water temperature on the ground & P-IV-I ${ }^{3}$ & ${ }^{\circ} \mathrm{C}$ & 7 & 10 & 27 & 13 \\
\hline 2. & The air temperature & & ${ }^{\circ} \mathrm{C}$ & 4 & 7 & 4 & 4 \\
\hline 3. & Electrical conductivity & P-IV-II ${ }^{3}$ & $\mu \mathrm{S} / \mathrm{cm}$ & 2660 & 8550 & 20,800 & 19,540 \\
\hline 4. & $\mathrm{pH}$ value & P-IV-6 $(A)^{3}$ & - & 7.91 & 7.68 & 8.59 & 8.65 \\
\hline 5. & The concentration of dissolved $\mathrm{O}_{2}$ & P-IV-12 (B) ${ }^{3}$ & $\mathrm{mg} / \mathrm{dm}^{3}$ & 7.22 & 7.11 & 0.19 & 0.21 \\
\hline 6. & Biological oxygen demand $\mathrm{BOD}_{5}$ & P-IV-13 $3^{3}$ & $\mathrm{mg} / \mathrm{dm}^{3}$ & 26 & 32 & 784 & 1275 \\
\hline 7. & Consumption of $\mathrm{KMnO}_{4}$ & P-IV-9a ${ }^{3}$ & $\mathrm{mg} / \mathrm{dm}^{3}$ & 3.73 & 6.76 & 446.82 & 459.46 \\
\hline 8. & Hardness of water & LCK 327 & ${ }^{0} \mathrm{dH}$ & 4.68 & 12.9 & 74.3 & 72.4 \\
\hline 9. & Nitrites & 8507 & $\mathrm{mg} / \mathrm{dm}^{3}$ & 0.010 & 0.011 & 0.310 & 0.400 \\
\hline 10. & Nitrates & 8171 & $\mathrm{mg} / \mathrm{dm}^{3}$ & 0.2 & $<0.1$ & 40 & 37 \\
\hline 11. & Phosphorus & LCK 349 & $\mathrm{mg} / \mathrm{dm}^{3}$ & $<0.15$ & $<0.15$ & 13.6 & 6.85 \\
\hline 12. & Potassium & 8049 & $\mathrm{mg} / \mathrm{dm}^{3}$ & 3.7 & 3.6 & 515.78 & 491.85 \\
\hline 13. & Chrome & LCK 313 & $\mathrm{mg} / \mathrm{dm}^{3}$ & $<0.03$ & 0.036 & 1.08 & 0.306 \\
\hline 14. & Iron & $\mathrm{P}-\mathrm{V}-17 / \mathrm{B}^{3}$ & $\mathrm{mg} / \mathrm{dm}^{3}$ & 7.395 & 7.477 & 18.320 & 10.095 \\
\hline 15. & Zink & ISO 8288/86 & $\mathrm{mg} / \mathrm{dm}^{3}$ & 0.619 & 1.367 & 1.444 & 1.517 \\
\hline 16. & Cadmium & LCK 308 & $\mathrm{mg} / \mathrm{dm}^{3}$ & $<0.02$ & $<0.02$ & 0.12 & 0.19 \\
\hline 17. & Nickel & ISO 8288/86 & $\mathrm{mg} / \mathrm{dm}^{3}$ & 3.947 & 3.998 & 4.613 & 5.029 \\
\hline 18. & Calcium & $\mathrm{P}-\mathrm{V}-22 / \mathrm{B}$ & $\mathrm{mg} / \mathrm{dm}^{3}$ & 15.152 & 58.542 & 51.613 & 58.150 \\
\hline 19. & Magnesium & $\mathrm{P}-\mathrm{V}-22 / \mathrm{B}$ & $\mathrm{mg} / \mathrm{dm}^{3}$ & 11.290 & 20.829 & 293.284 & 281.432 \\
\hline
\end{tabular}

Very low concentration of the dissolved oxygen in all tested samples, within the interval of $0.19-7.22 \mathrm{mg} / \mathrm{dm}^{3}$, point to the burdening of these leachate with organic matters, while very high conductivity range (2660 - 20,800 $\mu \mathrm{S} / \mathrm{cm}$ ) suggests that the total content of the dissolved salts is very high. Considering that extremely high heavy metals concentrations (Ni, Fe, Zn) were detected which are several times higher than Maximum allowed concentration (MAC) stated in the Directive on waters classification of the Republic of Serbia [30]-[32], these waters are considered extremely polluted and categorized as out of the legal limits.

Physical and chemical characteristics of the leachate waste from the illegal dump in Grabovac, obtained after treatment of waste samples using TCLP method are given in Table 3.

Based on the data shown in the Table 3, it can be concluded that the leachate from this illegal landfill in Grabovac, are detected of high heavy metals concentrations (Fe, Zn, Cd), also loaded with organic matter, and that the concentration of the dissolved salts is very high (the concentration of dissolved $\mathrm{O}_{2} 0.15-0.18 \mathrm{mg} / \mathrm{dm}^{3}$; electrical conductivity values were $820-918 \mu \mathrm{S} / \mathrm{cm}$ respectively). Although the results of physical and chemical testing show less pollution of the leachates compared to the collected leachates $\breve{S}$ and SK from the closed waste landfill Balaban, this is not conclusive result. Due to leaching of the deposited waste with atmospheric precipitation and direct leak in the environment and the neighboring river Ibar, it was necessary to analyze surface and ground waters in the vicinity of the landfill (Table 5).

The tailings deposit of the Mining-Metallurgy Chemical Company "Trepča" in Žitkovac (north of the town Zvečan), is located on the left bank of the river Ibar. It occupies surface of 150,000 $\mathrm{m}^{2}$ and was originally $20 \mathrm{~m}$ high. Although initially flotation tailings from the mineral processing in Zvečan, originating from processing of ores from mines "Stari Trg”, "Belo Brdo", “Crnac", “Ajvalija”, "Badovac”, “Kišnica” and "Novo Brdo”) were deposited there, in recent years it has become an illegal deposit of the municipal waste of the municipalities of 
Table 3. Physicochemical parameters of the leachate from the illegal waste landfill in Grabovac on the bank of the river Ibar.

\begin{tabular}{|c|c|c|c|c|c|}
\hline \multirow{2}{*}{ Nr. } & \multirow{2}{*}{ The investigated parameters } & \multirow{2}{*}{ Marking methods } & \multirow{2}{*}{ unit } & \multicolumn{2}{|c|}{ Leachate water } \\
\hline & & & & G 1 & G 2 \\
\hline 1. & Temperature of waste in the field & P-IV-I ${ }^{3}$ & ${ }^{\circ} \mathrm{C}$ & 7 & 7 \\
\hline 2. & The air temperature & & ${ }^{\circ} \mathrm{C}$ & 3 & 4 \\
\hline 3. & Electrical conductivity & P-IV-II ${ }^{3}$ & $\mu \mathrm{S} / \mathrm{cm}$ & 820 & 918 \\
\hline 4. & The $\mathrm{pH}$ value & P-IV-6 (A) ${ }^{3}$ & - & 7.39 & 7.41 \\
\hline 5. & The concentration of dissolved $\mathrm{O}_{2}$ & P-IV-12 (B) ${ }^{3}$ & $\mathrm{mg} / \mathrm{dm}^{3}$ & 0.18 & 0.15 \\
\hline 6. & Biological oxygen demand $\mathrm{BOD}_{5}$ & P-IV-13 $3^{3}$ & $\mathrm{mg} / \mathrm{dm}^{3}$ & 198 & 201 \\
\hline 7. & Chemical oxygen demand & P-IV- $-10^{3}$ & $\mathrm{mg} / \mathrm{dm}^{3}$ & 376 & 382 \\
\hline 8. & Hardness of water & LCK 327 & ${ }^{\circ} \mathrm{dH}$ & 71.3 & 70.4 \\
\hline 9. & Nitrites & 8507 & $\mathrm{mg} / \mathrm{dm}^{3}$ & 0.037 & 0.040 \\
\hline 11. & Phosphorus & LCK 349 & $\mathrm{mg} / \mathrm{dm}^{3}$ & 5.61 & 5.85 \\
\hline 12. & Potassium & 8049 & $\mathrm{mg} / \mathrm{dm}^{3}$ & 45.78 & 39.85 \\
\hline 13. & Chrome & LCK 313 & $\mathrm{mg} / \mathrm{dm}^{3}$ & 1.03 & 0.96 \\
\hline 14. & Iron & P-V-17/B ${ }^{3}$ & $\mathrm{mg} / \mathrm{dm}^{3}$ & 13.124 & 10.095 \\
\hline 15. & Zink & ISO 8288/86 & $\mathrm{mg} / \mathrm{dm}^{3}$ & 1.024 & 1.307 \\
\hline 16. & Cadmium & LCK 308 & $\mathrm{mg} / \mathrm{dm}^{3}$ & 0.24 & 0.19 \\
\hline 17. & Nickel & ISO 8288/86 & $\mathrm{mg} / \mathrm{dm}^{3}$ & 0.643 & 0.529 \\
\hline 18. & Calcium & $\mathrm{P}-\mathrm{V}-22 / \mathrm{B}$ & $\mathrm{mg} / \mathrm{dm}^{3}$ & 47.313 & 51.150 \\
\hline 19. & Magnesium & $\mathrm{P}-\mathrm{V}-22 / \mathrm{B}$ & $\mathrm{mg} / \mathrm{dm}^{3}$ & 284.384 & 279.432 \\
\hline
\end{tabular}

Zvečan and Mitrovica North. Physicochemical characteristics of the leachate from the waste deposited in the illegal dump in Žitkovac, obtained after treatment of waste samples by using TCLP method are presented in Table 4.

The observed very low concentration of the dissolved oxygen in the investigated samples (Table 4) from illegal deposit in Žitkovac $\left(0.15\right.$ and $\left.0.16 \mathrm{mg} / \mathrm{dm}^{3}\right)$ and high values of conductivity $(1120-1870 \mu \mathrm{S} / \mathrm{cm})$ indicate also loading of these leachates with organic matters and dissolved salts. Furthermore, concentrations of some heavy metals, similarly to some of the previously investigated locations are above the legal limits of MAC. Considering the fact that the municipal waste is deposited on the former tailings deposit from mineral processing plants, with direct leaking of the leachate in the environment and the river Ibar, some special attention was paid to investigation of presence of heavy metals in surface and ground waters running down flow from Grabovac, Žitkovac and deposit Balaban. The results of these investigations are presented in the Table 5.

Constant and complex pollution of the area to which the north part of Kosovo belongs, due to the presence of a large number of industrial landfills and illegal municipal solid waste landfills located in close vicinity or on the banks of the local rivers and the determined presence of heavy metals from industrial plants and landfills, and other hazardous and noxious substances, which are very high on the list of pollutants in this area due to their toxicities, has initiated the examination of the content of heavy metals in the river Ibar and groundwater's downstream from Grabovac and the landfill site Balaban ( $\mathrm{Pb}, \mathrm{Cr}, \mathrm{Ni}, \mathrm{Cd}, \mathrm{Zn}$ and $\mathrm{Hg}$ ). The test results are given in Table 5.

Conductivity is an important and fast method that measures the total dissolved ions and is directly related to total solids. The electrical conductivity (EC) of water samples in the Ibar river and groundwater ranges from 224 to $798 \mu \mathrm{S} / \mathrm{cm}$. Conductivity is also affected by temperature. The warmer waters have higher values of the conductivity. The water temperature is also a significant parameter that controls the inborn physical qualities of the 
Table 4. Physicochemical parameters of the leachate from the illegal waste landfill in Žitkovac.

\begin{tabular}{|c|c|c|c|c|c|}
\hline \multirow{2}{*}{ Nr. } & \multirow{2}{*}{ The investigated parameters } & \multirow{2}{*}{ Marking methods } & \multirow{2}{*}{ Unit } & \multicolumn{2}{|c|}{ Leachate water } \\
\hline & & & & $\check{Z} 1$ & $\check{Z ̌ 2}$ \\
\hline 1. & Temperature of waste in the field & P-IV-I ${ }^{3}$ & ${ }^{\circ} \mathrm{C}$ & 9 & 8 \\
\hline 2. & The air temperature & & ${ }^{\circ} \mathrm{C}$ & 4 & 4 \\
\hline 3. & Electrical conductivity & P-IV-II ${ }^{3}$ & $\mu \mathrm{S} / \mathrm{cm}$ & 1120 & 1870 \\
\hline 4. & The $\mathrm{pH}$ value & P-IV-6 (A) $)^{3}$ & - & 7.95 & 8.01 \\
\hline 5. & The concentration of dissolved $\mathrm{O}_{2}$ & P-IV-12 (B) ${ }^{3}$ & $\mathrm{mg} / \mathrm{dm}^{3}$ & 0.15 & 0.16 \\
\hline 6. & Biological oxygen demand $\mathrm{BOD}_{5}$ & P-IV-13 $3^{3}$ & $\mathrm{mg} / \mathrm{dm}^{3}$ & 438 & 572 \\
\hline 7. & Chemical oxygen demand & P-IV-10 $10^{3}$ & $\mathrm{mg} / \mathrm{dm}^{3}$ & 212 & 172 \\
\hline 8. & Hardness of water & LCK 327 & ${ }^{\circ} \mathrm{dH}$ & 65.3 & 72.4 \\
\hline 9. & Nitrites & 8507 & $\mathrm{mg} / \mathrm{dm}^{3}$ & 0.227 & 0.234 \\
\hline 11. & Phosphorus & LCK 349 & $\mathrm{mg} / \mathrm{dm}^{3}$ & 12.6 & 6.85 \\
\hline 12. & Potassium & 8049 & $\mathrm{mg} / \mathrm{dm}^{3}$ & 437.62 & 399.31 \\
\hline 13. & Chrome & LCK 313 & $\mathrm{mg} / \mathrm{dm}^{3}$ & 0.39 & 0.43 \\
\hline 14. & Iron & $\mathrm{P}-\mathrm{V}-17 / \mathrm{B}^{3}$ & $\mathrm{mg} / \mathrm{dm}^{3}$ & 13.25 & 15.90 \\
\hline 15. & Zink & ISO 8288/86 & $\mathrm{mg} / \mathrm{dm}^{3}$ & 1.51 & 2.13 \\
\hline 16. & Cadmium & LCK 308 & $\mathrm{mg} / \mathrm{dm}^{3}$ & 0.03 & 0.05 \\
\hline 17. & Nickel & ISO 8288/86 & $\mathrm{mg} / \mathrm{dm}^{3}$ & 3.561 & 4.181 \\
\hline 18. & Calcium & $\mathrm{P}-\mathrm{V}-22 / \mathrm{B}$ & $\mathrm{mg} / \mathrm{dm}^{3}$ & 49.28 & 53.75 \\
\hline 19. & Magnesium & $\mathrm{P}-\mathrm{V}-22 / \mathrm{B}$ & $\mathrm{mg} / \mathrm{dm}^{3}$ & 187.2 & 202.4 \\
\hline
\end{tabular}

Table 5. Physicochemical parameters and concentration of heavy metals in the surface water at the sites of Grabovac and Balaban and in well water at the sites of Grabovac.

\begin{tabular}{|c|c|c|c|c|c|c|c|c|c|c|c|c|c|c|c|}
\hline \multirow{2}{*}{$\begin{array}{c}\text { The } \\
\text { investigated } \\
\text { parameters }\end{array}$} & \multirow{2}{*}{ unit } & \multicolumn{6}{|c|}{ Surface water } & \multicolumn{3}{|c|}{ Well water } & \multicolumn{5}{|c|}{$\begin{array}{l}\text { The quality of water } \\
\text { by classes based on } \\
\text { parameter values }\end{array}$} \\
\hline & & $\begin{array}{c}\text { Grabovac } \\
\text { Apr./13 }\end{array}$ & $\begin{array}{c}\text { Grabovac } \\
\text { Sep. } / 13\end{array}$ & $\begin{array}{c}\text { Grabovac } \\
\text { Feb. } / 14\end{array}$ & $\begin{array}{l}\text { Balaban } \\
\text { Apr./13 }\end{array}$ & $\begin{array}{l}\text { Balaban } \\
\text { Sep./13 }\end{array}$ & $\begin{array}{c}\text { Balaban } \\
\text { Feb./13 }\end{array}$ & $\begin{array}{l}\text { Grabovac } \\
\text { Apr./13 }\end{array}$ & $\begin{array}{c}\text { Grabovac } \\
\text { Sep./13 }\end{array}$ & $\begin{array}{c}\text { Grabovac } \\
\text { Feb./13 }\end{array}$ & I & II & III & IV & $\mathrm{V}$ \\
\hline Scent & & $\begin{array}{l}\text { the } \\
\text { smell } \\
\text { of rot }\end{array}$ & $\begin{array}{l}\text { the } \\
\text { smell } \\
\text { of rot }\end{array}$ & $\begin{array}{l}\text { the } \\
\text { smell } \\
\text { of rot }\end{array}$ & $\begin{array}{l}\text { the } \\
\text { smell } \\
\text { of rot }\end{array}$ & $\begin{array}{l}\text { the } \\
\text { smell } \\
\text { of rot }\end{array}$ & $\begin{array}{l}\text { the } \\
\text { smell } \\
\text { of rot }\end{array}$ & without & without & without & & & & & \\
\hline Colors & NTU & 2.1 & 2.0 & 2.2 & 2.1 & 1.9 & 2.1 & no color & no color & no color & & & & & \\
\hline $\begin{array}{l}\text { Suspended } \\
\text { solids }\end{array}$ & $\mathrm{mg} / \mathrm{dm}^{3}$ & 21 & 18 & 19 & 9.5 & 14 & 11 & 4 & 4 & 4 & 25 & 25 & - & - & - \\
\hline $\begin{array}{l}\text { The water } \\
\text { temperature } \\
\text { in the field }\end{array}$ & ${ }^{\circ} \mathrm{C}$ & 12 & 16 & 9 & 8 & 15 & 6 & 9 & 10 & 9 & & & & & \\
\hline $\begin{array}{c}\text { The air } \\
\text { temperature }\end{array}$ & ${ }^{\circ} \mathrm{C}$ & 10 & 15 & 7 & 7 & 14 & 3 & 10 & 15 & 8 & & & & & \\
\hline $\begin{array}{c}\text { Electrical } \\
\text { conductivity }\end{array}$ & $\mathrm{mg} / \mathrm{dm}^{3}$ & 442 & 508 & 451 & 442 & 395 & 369 & 236 & 224 & 230 & $<1000$ & 1000 & 1500 & 3000 & $>3000$ \\
\hline $\begin{array}{l}\text { The } \mathrm{pH} \\
\text { value }\end{array}$ & $\mathrm{mg} / \mathrm{dm}^{3}$ & 7.9 & 8.1 & 8.2 & 7.8 & 8.1 & 7.9 & 7.8 & 7.9 & 7.9 & $\begin{array}{c}6.5 \\
- \\
8.5\end{array}$ & $\begin{array}{c}6.5 \\
- \\
8.5\end{array}$ & $\begin{array}{c}6.5 \\
- \\
8.5\end{array}$ & $\begin{array}{c}6.5 \\
- \\
8.5\end{array}$ & $\begin{array}{c}<6 . \\
\text { or } \\
>8.5\end{array}$ \\
\hline $\begin{array}{c}\text { The } \\
\text { concentration } \\
\text { of } \\
\text { dissolved } \mathrm{O}_{2}\end{array}$ & $\mathrm{mg} / \mathrm{dm}^{3}$ & 5.4 & 5.3 & 5.4 & 6.1 & 6.3 & 6.2 & 8.9 & 8.7 & 8.8 & - & 7 & 5 & 4 & $<4$ \\
\hline
\end{tabular}




\begin{tabular}{|c|c|c|c|c|c|c|c|c|c|c|c|c|c|c|c|}
\hline $\begin{array}{c}\text { Biological } \\
\text { oxygen } \\
\text { demand } \mathrm{BOD}_{5}\end{array}$ & $\mathrm{mg} / \mathrm{dm}^{3}$ & 7.2 & 6.9 & 7.1 & 5.8 & 5.8 & 5.7 & 3.9 & 4.2 & 4.5 & - & 5 & 7 & 25 & $>25$ \\
\hline $\begin{array}{l}\text { Chemical } \\
\text { oxygen } \\
\text { demand }\end{array}$ & $\mathrm{mg} / \mathrm{dm}^{3}$ & 17.3 & 16.5 & 17.2 & 12.8 & 13.7 & 12.6 & 5.9 & 5.5 & 5.7 & 5 & 10 & 20 & 50 & $>50$ \\
\hline $\begin{array}{l}\text { Hardness } \\
\text { of water }\end{array}$ & ${ }^{0} \mathrm{dH}$ & 198 & 189 & 170 & 201 & 203 & 199 & 175 & 178 & 175 & & & & & \\
\hline Nitrates & $\mathrm{mg} / \mathrm{dm}^{3}$ & 1.2 & 0.8 & 0.65 & 0.39 & 0.47 & 0.34 & 0.02 & 0.02 & 0.02 & 0.01 & 0.03 & 0.12 & 0.3 & $>0.3$ \\
\hline Phosphates & $\mathrm{mg} / \mathrm{dm}^{3}$ & 0.1 & 0.07 & 0.06 & 0.1 & 0.08 & 0.05 & 0.03 & 0.03 & 0.02 & - & 0.1 & 0.2 & 0.5 & $>0.5$ \\
\hline Sulfates & $\mathrm{mg} / \mathrm{dm}^{3}$ & 95.50 & 94.66 & 88.45 & 81.74 & 76.63 & 75.41 & 43.72 & 56.80 & 59.67 & 50 & 100 & 200 & 300 & $>300$ \\
\hline Chloride & $\mathrm{mg} / \mathrm{dm}^{3}$ & 18.4 & 18.3 & 18.1 & 18.3 & 18.7 & 18.1 & 10.3 & 10.5 & 10.1 & 50 & 100 & 150 & 250 & $>250$ \\
\hline Chrome & $\mu \mathrm{g} / \mathrm{dm}^{3}$ & 0.09 & 2.58 & 2.76 & 0.28 & 0.27 & 2.61 & 0.05 & $<0.05$ & 0.05 & 25 & 50 & 100 & 250 & $>250$ \\
\hline Nickel & $\mu \mathrm{g} / \mathrm{dm}^{3}$ & 1.8 & 6.59 & 3.12 & 0.10 & 0.09 & 3.28 & 0.18 & 0.16 & 0.17 & 20 & 25 & 50 & 100 & $>100$ \\
\hline Lead & $\mu \mathrm{g} / \mathrm{dm}^{3}$ & 193.22 & 148.31 & 132.15 & 54.68 & 39.90 & 27.62 & 12.97 & 18.85 & 13.81 & 50 & 100 & 100 & 200 & $>200$ \\
\hline Cadmium & $\mu \mathrm{g} / \mathrm{dm}^{3}$ & 5.0 & 17.68 & 0.10 & 0.06 & 0.06 & 13.12 & 0.06 & 0.05 & 0.05 & $\begin{array}{c}5 \\
\text { and }<\end{array}$ & $\begin{array}{c}30 \\
\text { and }<\end{array}$ & $100<$ & 200 & $>200$ \\
\hline Zink & $\mu \mathrm{g} / \mathrm{dm}^{3}$ & 3.24 & 7.24 & 3.21 & 0.06 & $<0.05$ & 0.81 & 0.08 & 0.09 & 0.10 & 10 & 100 & 200 & 500 & 1000 \\
\hline Mercury & $\mu \mathrm{g} / \mathrm{dm}^{3}$ & 0.01 & 0.35 & 0.43 & 0.03 & 0.02 & 0.37 & 5.98 & 4.99 & 5.48 & 5 & 5 & $<10$ & 10 & $>10$ \\
\hline Iron & $\mu \mathrm{g} / \mathrm{dm}^{3}$ & 94 & 75 & 80 & 74 & 75 & 56 & 47 & 40 & 38 & 100 & 200 & 500 & 1000 & 2000 \\
\hline Copper & $\mu \mathrm{g} / \mathrm{dm}^{3}$ & 112 & 124 & 310 & 85 & 57 & 65 & 18 & 22 & 19 & 10 & 100 & 200 & 500 & 1000 \\
\hline Calcium & $\mathrm{mg} / \mathrm{dm}^{3}$ & 64.7 & 67.6 & 65.8 & 85.6 & 70.7 & 69.2 & 60.5 & 57.3 & 67.4 & - & - & - & - & - \\
\hline Magnesium & $\mathrm{mg} / \mathrm{dm}^{3}$ & 17.4 & 19.2 & 18.7 & 26.5 & 21.4 & 20.8 & 14.1 & 18.4 & 11.9 & - & - & - & - & - \\
\hline Phenols & $\mathrm{mg} / \mathrm{dm}^{3}$ & 0.008 & 0.006 & 0.004 & 0.006 & 0.005 & 0.004 & 0.002 & 0.001 & 0.002 & 0.001 & 0.001 & I & I & I \\
\hline
\end{tabular}

water. In this study, the surface water temperature ranged between $6^{\circ} \mathrm{C}$ and $16^{\circ} \mathrm{C}$, while the temperature of the ground water was in the range of $9^{\circ} \mathrm{C}-10^{\circ} \mathrm{C}$. The $\mathrm{pH}$ is a measurement of the acidity or basic quality of water. Extremely high or low $\mathrm{pH}$ levels have a significant effect for most aquatic organisms. The $\mathrm{pH}$ of the water changes even slightly. In this study the $\mathrm{pH}$ levels range from 7.8 to 8.2. Turbidity is another important parameter of water pollution. The present study shows the turbidity of river in the range of 19 - 98 NTU, while the turbidity of groundwater is 1 NTU. The highest desirable limits for turbidity are 5 NTU and maximum permissible limit 50 NTU [29] [32]. In all locations the value of turbidity present are not within the desirable limit. It reveals that the river pollution is high. Dissolved oxygen in water is an essential and important parameter for aquatic life. Deficiency of dissolved oxygen comes as a result of anaerobic decomposition of organic waste [30] [33]. DO in our study ranges from 5.3 to $8.9 \mathrm{mg} / \mathrm{dm}^{3}$. Biological Oxygen Demand (BOD) is an important parameter used to assess the organic pollution. When surface water is having BOD more than $5 \mathrm{mg} / \mathrm{dm}^{3}$, it is unsafe for domestic use. In our study, all samples of surface water with BOD above permissible limits (5.7 - $7.2 \mathrm{mg} / \mathrm{dm}^{3}$ ). Therefore, a high value of BOD confirms the present situation of highly contaminated river Ibar.

Based on the results presented in Table 5 and the references [30]-[32] and exceeding limits of certain physical and chemical parameters (concentration of dissolved $\mathrm{O}_{2}, \mathrm{COD}, \mathrm{BOD}_{5}$, Sulphates, Nitrites and Phenols) and considering determined extremely high concentration of lead and copper in three of the samples of surface water and cadmium in the two, the surface waters of the investigated locations are classified in the III, IV or V class, which designates poor quality of the water, unusable for irrigation of agricultural crops. According to reference [34] water quality of the river Ibar is decreasing. What is particularly worrying is that increased contents of mercury and phenols were found in well water at the location in Grabovac, which is used for drinking. Activity in thermal power plants, coal mines, and impact of existing ash, industrial and municipal landfills, pesticides, electrical equipment (batteries, lamps, switches) smelting and fossil-fuel combustion, result in wastewater pollution, that are subsequently discharged directly into the rivers Sitnica and Ibar without any prior treatment [35]. Existence of such complex pollution requires immediate action, especially given that polluted water can cause serious consequences for human health, plants and animals, and the whole environment. Advanced wastewater treatments such as classification, treatment, flocculation and filtration of the discharged waters would enable their re-use and minimize the pollution. 
Comparing the results of the analysis of the leachate collected in schacht (S3) and sewer (SK4) in the landfill Balaban, where there is no direct contact between leachate of landfill and surface and ground waters in the environment, with the results for leachate of illegal and informal dumps (Grabovac and Žitkovac) and analysis of the investigated parameters of surface and ground waters (Table 5), it can be concluded that the waste, disposed of in this and other similar locations, is washed by atmospheric precipitation that leach toxic and harmful substances and release the leachate into the immediate environment: soil, surface water and groundwater, and agricultural crops, plants and animals and finally, the human body. Pathways of metal transfer in the terrestrial food web along with the selected references for each pathway [1] are shown in Figure 5.

\subsection{The Measures for the Rehabilitation of Existing and Preventing Future Pollution}

As a first step it would be necessary to find an adequate location for the sanitary landfill of municipal waste and to change the existing attitude towards waste as waste now represents "the raw material in the wrong place", also to apply hierarchy approach to waste management (reduce, reuse, recycle, recover and residual management) and to implement an adequate methods for rehabilitation and for prevention of future pollution.

Construction of a drainage channel at borders of a landfill (the so-called collector), which would be connected to a network of municipal waste water and drainage pipes placed into the body of illegal dumps, could prevent the pollution of surface and ground water, and thus contamination of crops as well as spread of pollution in the region. A schematic presentation of links of leachate from illegal dumps with a network of urban wastewater is presented in Figure 6.

Figure 7 shows examples of drainage pipes placement into the landfill body and collecting the filtrate water in the collection basin lined with an impermeable foil.

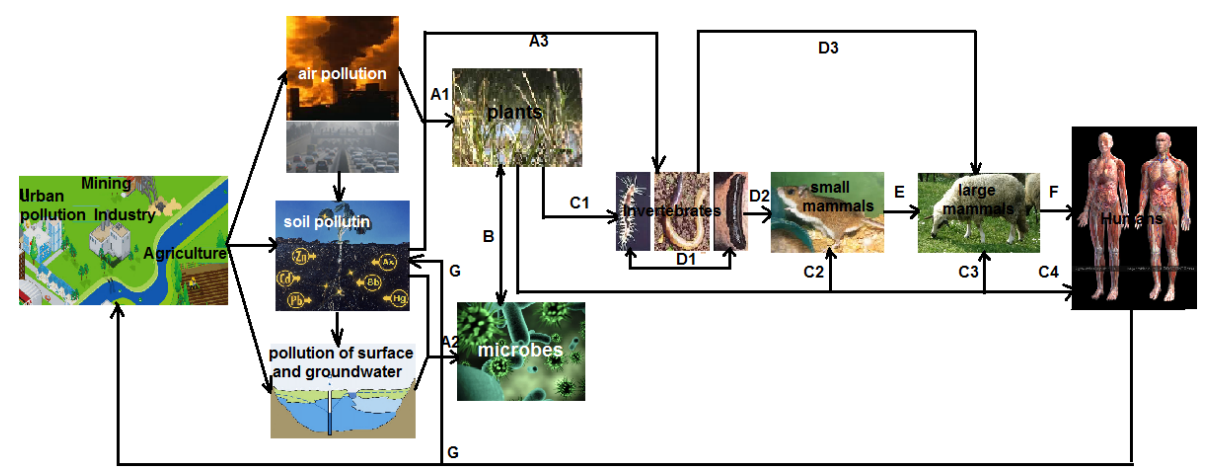

Figure 5. Pathways of metal transfer in the terrestrial food web and selected references for each pathway (A1-G) [1]: (A1) [36]-[38]; (A2) [39]-[41]; (A3) [42] [43]; (B) [44]-[46]; (C1) [47]-[51]; (C2) [52]-[54]; (C3) [55]-[57]; (C4) [58]-[63]; (D2) [64]-[66]; (D3) [67]; (F) [68]; (G) [69]-[72].

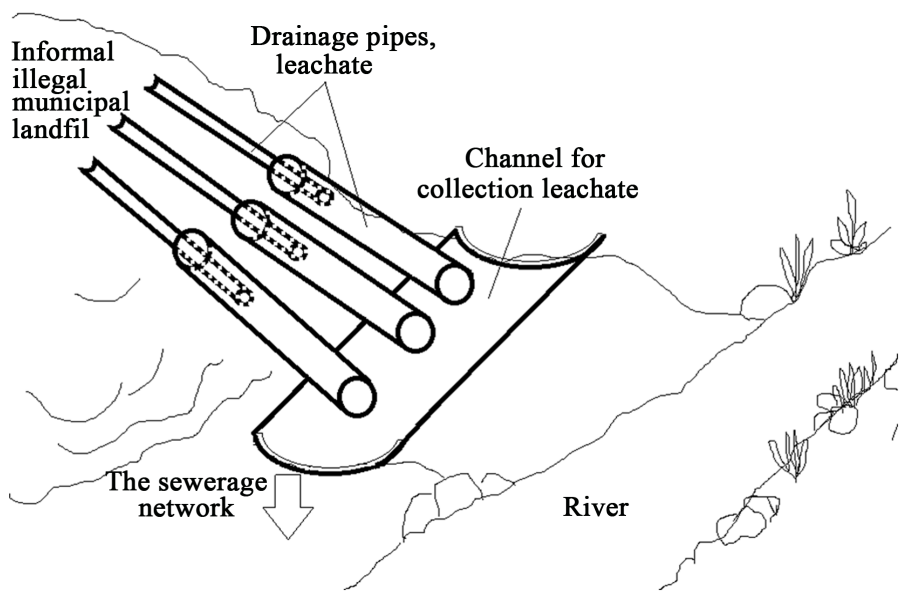

Figure 6. Landfill leachate drainage system. 


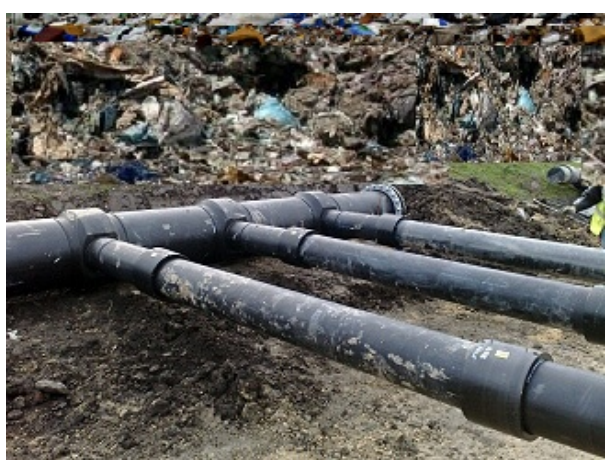

(a)

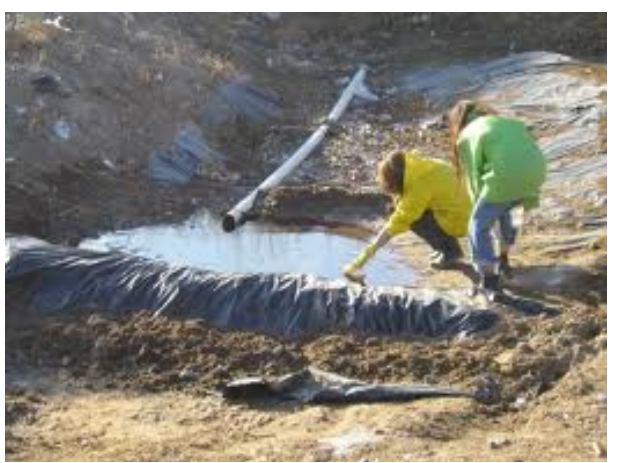

(b)

Figure 7. Examples of remediation: (a) drainage pipes placement and (b) impermeable thin substrate.

Including of landfill leachate into the system of municipal waste water offers a possibility for purification of municipal wastewater, industrial wastewater and leachate using unique Membrane Bio Reactors (MBR) technology. Performed analysis shows that, after the MBR wastewater treatment, quality of an effluent is better than legally required [73] [74].

In the process of treating waste and leachate with the MBR technology, the excess waste sludge is minimal, it is adequate and well stabilized, which enables its further processing. The amount of sludge in other processes is about 0.6 - $0.7 \mathrm{~kg}$ per $\mathrm{kg}$ of BOD, depending on temperature, sludge age and effluent quality.

Technological procedure of sludge stabilization is based on the process of solidification, with a purpose to convert the waste and sludge (hereinafter, on the basis of the definition of waste, used only the term waste) [75] [76], with at least one dangerous characteristic, to the state in which its constituents are immobilized in the way that doesn't make them dangerous for the environment [77] [78].

This technological process is a physical and chemical procedure in which a reaction takes place between waste and additives based on calcium (calcium oxide $\mathrm{CaO}$ and calcium hydroxide $\mathrm{Ca}(\mathrm{OH})_{2}$. During this reaction, the waste molecule is permanently transformed into a new neutral product. The process takes place in a reactor under sub-pressure, so there is no emission of pollutants into the air and thus no pollution of the environment. The final product of the permanent transformation of the waste mixture is completely neutral and it can be used for various applications [79].

\section{Conclusion}

Results of physicochemical parameters and determined contents of heavy metals leaching from dumps in the northern part of Kosovska Mitrovica suggest an exceptional pollution. High contents of organic pollutants and heavy metals found on sites near illegal waste dumps in Grabovac and Žitkovac, as well as the concentrations of these metals in groundwater (well) in Grabovac. Particularly is disturbing increased mercury content in groundwater in Grabovac, content of copper, especially, in surface water in Grabovac and multiple increased concentrations of phenol in samples of surface and ground water. Given that the sampling was performed in three different periods (April 2013, September 2013 and February 2014), it can be concluded that pollution is present in all experimental periods. Constant, growing environmental degradation requires urgent interventions in waste management and implementation of accessible and effective method for reducing and preventing environmental pollution and the harmful and hazardous substances from entering the food chain. In this paper, we proposed a method of rehabilitation and prevention of further pollution by applying of Membrane Bio Reactor (MBR) plants for treatment of municipal, industrial and leachate from informal landfills, which include the process of stabilization of residual sludge. This technological procedure is considered as one of allowed and recommended technologies in Europe for industrial and municipal waste and leachate recycling, as well as the best available technology that does not require any excessive costs of waste management and does not pollute the environment.

\section{Acknowledgements}

This research is conducted as a part of project No. III 43007, The investigated of climate change and their impact 
on the environment, monitoring impact, adaptation and mitigation; This study is supported by the Ministry of Education, Science and Technological development of the Republic of Serbia.

\section{References}

[1] Gall, J.E., Boyd, R.S. and Rajakaruna, N. (2015) Transfer of Heavy Metals through Terrestrial Food Webs: A Review. Environmental Monitoring and Assessment, 187, 187-201. http://dx.doi.org/10.1007/s10661-015-4436-3

[2] Sánchez, M.L. (Ed) (2008) Causes and Effects of Heavy Metal Pollution. Nova Science Publishers, New York, 173.

[3] Wuana, R.A. and Okieimen, F.E. (2011) Heavy Metals in Contaminated Soils: A Review of Sources, Chemistry, Risks and Best Available Strategies for Remediation. ISRN Ecology, 1-20. http://dx.doi.org/10.5402/2011/402647

[4] Goyer, R.A. (1996) Toxic Effect of Metals. In: Casarett and Doull's Toxicology: The Basic Science of Poisons, 3th Edition, Macmillan Publishing Company, New York, 582-635.

[5] Clemente, R., Dickinson, N.M. and Lepp, N.W. (2008) Mobility of Metals and Metalloids in a Multi-Element Contaminated Soil 20 Years after Cessation of the Pollution Source Activity. Environmental Pollution, 155, 254-261. http://dx.doi.org/10.1016/j.envpol.2007.11.024

[6] Goodarzi, F., Sanei, H., Garrett, R.G. and Duncan, W.F. (2002) Accumulation of Trace Elements on the Surface Soil around the Trail Smelter, British Columbia, Canada. Environmental Geology, 43, 29-38. http://dx.doi.org/10.1007/s00254-002-0634-8

[7] Kaasalainen, M. and Yli-Halla, M. (2003) Use of Sequential Extraction to Assess Metal Partitioning in Soil. Environmental Pollution, 126, 225-233. http://dx.doi.org/10.1016/S0269-7491(03)00191-X

[8] Sterckeman, T., Douay, F., Proix, N. and Fourrier, H. (2000) Vertical Distribution of Cd, Pb and Zn in Soils near Smelters in the North of France. Environmental Pollution, 107, 377-389. http://dx.doi.org/10.1016/S0269-7491(99)00165-7

[9] Nannoni, F., Protano, G. and Riccobono, F. (2011) Fractionation and Geochemical Mobility of Heavy Elements in Soils of a Mining Area in Northern Kosovo. Geoderma, 161, 63-73. http://dx.doi.org/10.1016/j.geoderma.2010.12.008

[10] Masoner, J.R. and Cozzarelli, I.M. (2015) Spatial and Temporal Migration of a Landfill Leachate Plume in Alluvium. Water, Air, and Soil Pollution, 226, 226-241. http://dx.doi.org/10.1007/s11270-014-2261-x

[11] Yu, Y., Chen, Z., Guo, Z., Liao, Z., Yang, L., Wang, J. and Chen, Z. (2015) Removal of Refractory Contaminants in Municipal Landfill Leachate by Hydrogen, Oxygen and Palladium: A Novel Approach of Hydroxyl Radical Production. Journal of Hazardous Materials, 287, 349-355. http://dx.doi.org/10.1016/j.jhazmat.2015.01.070

[12] Bahaa-Eldin, E.A.R., Yusoff, I., Rahim, S.A., Zuhairi, W.Y.W. and Ghani, M.R.A. (2011) Tracing Subsurface Migration of Contaminants from an Abandoned Municipal Landfill. Environmental Earth Sciences, 63, 1043-1055. http://dx.doi.org/10.1007/s12665-010-0780-3

[13] Bjerg, P.L., Albrechtsen, H.-J., Kjeldsen, P., Christensen, T.H. and Cozzarelli, I.M. (2013) The Biogeochemistry of Contaminant Groundwater Plumes Arising from Waste Disposal Facilities. In: Holland, H.D. and Turekian, K.K., Eds., Treatise on Geochemistry, Second Edition, Vol. 11, Elsevier Science, Oxford, 573-605.

[14] Rainbow, P.S., Liu, F. and Wang, W.-X. (2015) Metal Accumulation and Toxicity: The Critical Accumulated Concentration of Metabolically Available Zinc in an Oyster Model. Aquatic Toxicology, 162, 102-108. http://dx.doi.org/10.1016/j.aquatox.2015.03.007

[15] Čejka, P., Horák, T., Dvořák, J., Čulík, J., Jurková, M., Kellner, V. and Hašková, D. (2011) Monitoring of the Distribution of Some Heavy Metals during Brewing Process. Ecological Chemistry and Engineering S, 18, 67-74.

[16] Barcelos, G.R.M., Souza, M.F.D., Oliveira, A.T.S.D., Lengert, A.V.H., Oliveira, M.T.D., Camargo, R.B.D.O.G., Grotto, D., Valentini, J., Garcia, S.C., Braga, G.T.L., Cólus, I.M.D.S., Adeyemi, J. and Barbosa, F. (2015) Effects of Genetic Polymorphisms on Antioxidant Status and Concentrations of the Metals in the Blood of Riverside Amazonian Communities Co-Exposed to Hg and Pb. Environmental Research, 138, 224-232. http://dx.doi.org/10.1016/j.envres.2015.02.017

[17] Liu, X., Zhai, Y., Zhu, Y., Liu, Y., Chen, H., Li, P., Peng, C., Xu, B., Li, C. and Zeng, G. (2015) Mass Concentration and Health Risk Assessment of Heavy Metals in Size-Segregated Airborne Particulate Matter in Changsha. Science of the Total Environment, 517, 215-221. http://dx.doi.org/10.1016/j.scitotenv.2015.02.066

[18] Schwarzbauer, J., Heim, S., Brinker, S. and Littke, R. (2002) Occurrence and Alteration of Organic Contaminants in Seepage and Leakage Water from a Waste Deposit Landfill. Water Research, 36, 2275-2287. http://dx.doi.org/10.1016/S0043-1354(01)00452-3

[19] Rasmussen, S., Chen, L., Deamer, D., Krakauer, D.C., Packard, N.H., Stadler, P.F. and Bedau, M.A. (2004) Transitions from Nonliving to Living Matter. Science, 303, 963-965. http://dx.doi.org/10.1126/science.1093669 
[20] Baun, A., Ledin, A., Reitzel, L.A., Bjerg, P.L. and Christensen, T.H. (2004) Xenobiotic Organic Compounds in Leachates from 10 Danish MSW Landfills-Chemical Analysis and Toxicity Tests. Water Research, 38, 3845-3858. http://dx.doi.org/10.1016/j.watres.2004.07.006

[21] Hoehn, E., Johnson, C.A., Huggenberger, P., Amirbahman, A., Peter, A. and Zweifel, H.R. (2000) Investigative Strategies and Risk Assessment of Old Unlined Municipal Solid Waste Landfills. Waste Management Research, 18, 577-589. http://dx.doi.org/10.1177/0734242X0001800609

[22] Inyang, H.I. (2004) Modeling the Long-Term Performance of Waste Containment Systems. Environmental Science and Technology, 38, 328A-334A.

[23] Schwarzbauer, J., Heim, S., Krooss, B. and Littke, R. (2006) Analysis of Undisturbed Layers of a Waste Deposit Landfill-Insights into the Transformation and Transport of Organic Contaminants. Organic Geochemistry, 37, 2026-2045. http://dx.doi.org/10.1016/j.orggeochem.2006.08.008

[24] http://www.google.rs/maps/2015/nov.25

[25] US EPA (1990) Test Methods for Evaluating Solid Waste Method 1311. US EPA, Washington DC.

[26] State of Connecticut Department of Environmental Protection Reasonable Confidence Protocols Quality Assurance and Quality Control Requirements Toxicity Characteristic Leaching Procedure by SW-846 Method 1311, Version 2.0 December 2006. http://www.ct.gov/deep/lib/deep/site_clean_up/guidance/rcp/rcp_method_1311_tclp.pdf

[27] US EPA Method 3015 (1994) Microwave Assisted Acid Digestion of Aqueous Samples and Extracts.

[28] US EPA 6010C (2007) Inductively Coupled Plasma-Atomic Emission Spectrometry.

[29] Matavulj, M. (1997) Determination of Water Phosphates’ Activity—New Approach for Biodegradable Organic Load of Surface Freshwater Monitoring. Proceedings of IAAS Seminar "Future Is in Aquaculture”, Novi Sad, 2-9 July 1997, 9-11.

[30] Council Directive 75/440/EEC (1975) Concerning the Quality Required of Surface Water Intended for the Abstraction of Drinking Water in the Member States. OJ L 194, 26-31.

[31] Regulative of Limited Concentration of the Pollutants in Surface, Ground Waters and Sediments, (Official Gazette of RS No 50/2012).

[32] Regulative of Limited Concentrations of Primary Hazardous Substances Polluting Surface Waters and Deadlines for Reaching the Limits (Official Gazette of RS No. 24/2014).

[33] Directive of Waters Classification RS, O.G. No 46/91, 53/93, 48/94.54/96.

[34] Ocokoljić, M., Milijašević, D. and Milanović, A. (2009) Rivers Classification of Serbia According to the Theirs Pollutions Degree, COLLECTION OF PAPERS-Faculty of Geography at the University of Belgrade: LVII, 504.45.054. (497.11), 6-18.

[35] Baruti, B., Malollari, I., Ferati, S., Lajci, N., Hoda, S., Kelmendi, M., Dobroshi, F. and Hoxha, P. (2014) Environmental Impacts of Wastewater Discharged from Kosovo Thermal Power Plants into the Sitnica River. Journal of Environmental Protection and Ecology, 15, 819-824.

[36] Gall, J.E. and Rajakaruna, N. (2013) The Physiology, Functional Genomics, and Applied Ecology of Heavy Metal-Tolerant Brassicaceae. In: Minglin, L., Ed., Brassicaceae: Characterization, Functional Genomics and Health Benefits, Hauppauge, Nova, 121-148.

[37] Van der Ent, A., Baker, A.J.M., Reeves, R.D., Pollard, A.J. and Schat, H. (2013) Hyperaccumulators of Metal and Metalloid Trace Elements: Facts and Fiction. Plant and Soil, 362, 319-334. http://dx.doi.org/10.1007/s11104-012-1287-3

[38] Pollard, A.J., Reeves, R.D. and Baker, A.J.M. (2014) Facultative Hyperaccumulation of Heavy Metals and Metalloids. Plant Science, 217, 8-17. http://dx.doi.org/10.1016/j.plantsci.2013.11.011

[39] Giller, K.E., Witter, E. and McGrath, S.P. (2009) Heavy Metals and Soil Microbes. Soil Biology and Biochemistry, 41, 2031-2037. http://dx.doi.org/10.1016/j.soilbio.2009.04.026

[40] Gadd, G.M. (2010) Metals, Minerals and Microbes: Geomicrobiology and Bioremediation. Microbiology, 156, 609-643. http://dx.doi.org/10.1099/mic.0.037143-0

[41] Boshoff, M., De Jonge, M., Dardenne, F., Blust, R. and Bervoets, L. (2014) The Impact of Metal Pollution on Soil Faunal and Microbial Activity in Two Grassland Ecosystems. Environmental Research, 134, 169-180. http://dx.doi.org/10.1016/j.envres.2014.06.024

[42] Heikens, A., Peijnenburg, W.J.G.M. and Hendriks, A.J. (2001) Bioaccumulation of Heavy Metals in Terrestrial Invertebrates. Environmental Pollution, 113, 385-393. http://dx.doi.org/10.1016/S0269-7491(00)00179-2

[43] Hobbelen, P.H.F., Koolhaas, J.E. and Van Gestel, C.A.M. (2006) Bioaccumulation of Heavy Metals in the Earthworms Lumbricus rubellus and Aporrectodea caliginosa in Relation to Total and Available Metal Concentrations in Field Soils. Environmental Pollution, 144, 639-646. http://dx.doi.org/10.1016/j.envpol.2006.01.019 
[44] Wenzel, W.W. (2009) Rhizosphere Processes and Management in Plant-Assisted Bioremediation (Phytoremediation) of Soils. Plant and Soil, 321, 385-408. http://dx.doi.org/10.1007/s11104-008-9686-1

[45] Hol, W.H., de Boer, W., Termorshuizen, A.J., Meyer, K.M., Schneider, J.H.M., van Dam, N.M., van Veen, J.A. and van der Putten, W.H. (2010) Reduction of Rare Soil Microbes Modifies Plant-Herbivore Interactions. Ecology Letters, 13, 292-301. http://dx.doi.org/10.1111/j.1461-0248.2009.01424.x

[46] Kothe, E. and Büchel, G. (2014) Umbrella: Using Microbes for the Regulation of Heavy Metal Mobility at Ecosystem and Landscape Scale. Environmental Science and Pollution Research, 21, 6761-6764. http://dx.doi.org/10.1007/s11356-014-2689-y

[47] Janssens, T.K.S., Roelofs, D. and van Straalen, N.M. (2009) Molecular Mechanisms of Heavy Metal Tolerance and Evolution in Invertebrates. Insect Science, 16, 3-18. http://dx.doi.org/10.1111/j.1744-7917.2009.00249.x

[48] Migula, P., Przybylowicz, W.J., Nakonieczny, M., Augustyniak, M., Tarnawska, M. and Mesjasz-Przybylowicz, J. (2011) Micro-PIXE Studies of Ni-Elimination Strategies in Representatives of Two Families of Beetles Feeding on Ni-Hyperaccumulating Plant Berkheya coddii. X-Ray Spectrometry, 40, 194-197. http://dx.doi.org/10.1002/xrs.1310

[49] Nica, D.V., Bura, M., Gergen, I., Harmanescu, M. and Bordean, D. (2012) Bioaccumulative and Conchological Assessment of Heavy Metal Transfer in a Soil-Plant-Snail Food Chain. Chemistry Central Journal, 6, 55. http://dx.doi.org/10.1186/1752-153X-6-55

[50] Meindl, G.A., Bain, D.J. and Ashman, T.-L. (2014) Variation in Nickel Accumulation in Leaves, Reproductive Organs and Floral Rewards in Two Hyperaccumulating Brassicaceae Species. Plant and Soil, 383, 349-356. http://dx.doi.org/10.1007/s11104-014-2184-8

[51] Bourioug, M., Gimbert, F., Alaoui-Sehmer, L., Benbrahim, M., Aleya, L. and Alaoui-Sossé, B. (2015) Sewage Sludge Application in a Plantation: Effects on Trace Metal Transfer in Soil-Plant-Snail Continuum. Science of the Total Environment, 502, 309-314. http://dx.doi.org/10.1016/j.scitotenv.2014.09.022

[52] Lopes, P.A., Viegas-Crespo, A.M., Nunes, A.C., Pinheiro, T., Marques, C., Santos, M.C. and Mathias, M.L. (2002) Influence of Age, Sex, and Sexual Activity on Trace Element Levels and Antioxidant Enzyme Activities in Field Mice (Apodemus sylvaticus and Mus pretus). Biological Trace Element Research, 85, 227-239. http://dx.doi.org/10.1385/BTER:85:3:227

[53] Beernaert, J., Scheirs, J., Leirs, H., Blust, R. and Verhagen, R. (2007) Non-Destructive Pollution Exposure Assessment by Means of Wood Mice Hair. Environmental Pollution, 145, 443-451. http://dx.doi.org/10.1016/j.envpol.2006.04.025

[54] Sánchez-Chardi, A., Penarroja-Matutano, C., Ribeiro, C.A.O. and Nadal, J. (2007) Bioaccumulation of Metals and Effects of a Landfill in Small Mammals, Part II. The Wood Mouse, Apodemus sylvaticus. Chemosphere, 70, 101-109. http://dx.doi.org/10.1016/j.chemosphere.2007.06.047

[55] Reglero, M.M., Monsalve-González, L., Taggart, M.A. and Mateo, R. (2008) Transfer of Metals to Plants and Red Deer in an Old Lead Mining Area in Spain. Science of the Total Environment, 406, 287-297. http://dx.doi.org/10.1016/j.scitotenv.2008.06.001

[56] Phillips, C.J.C. and Tudoreanu, L. (2011) A Model of Cadmium in the Liver and Kidney of Sheep Derived from Soil and Dietary Characteristics. Journal of the Science of Food and Agriculture, 91, 370-376. http://dx.doi.org/10.1002/jsfa.4195

[57] Roggeman, S., van den Brink, N., Van Praet, N., Blust, R. and Bervoets, L. (2013) Metal Exposure and Accumulation Patterns in Free-Range Cows (Bos taurus) in a Contaminated Natural Area: Influence of Spatial and Social Behavior. Environmental Pollution, 172, 186-199. http://dx.doi.org/10.1016/j.envpol.2012.09.006

[58] Cao, H., Chen, J., Zhang, J., Zhang, H., Qiao, L. and Men, Y. (2010) Heavy Metals in Rice and Garden Vegetables and Their Potential Health Risks to Inhabitants in the Vicinity of an Industrial Zone in Jiangsu, China. Journal of Environmental Sciences, 22, 1792-1799. http://dx.doi.org/10.1016/S1001-0742(09)60321-1

[59] Sahoo, P.K. and Kim, K. (2013) A Review of the Arsenic Concentration in Paddy Rice from the Perspective of Geosciences. Geosciences Journal, 17, 107-122. http://dx.doi.org/10.1007/s12303-013-0004-4

[60] Street, R.A. (2012) Heavy Metals in Medicinal Plant Products: An African Perspective. South African Journal of Botany, 82, 67-74. http://dx.doi.org/10.1016/j.sajb.2012.07.013

[61] Peterson, L.R., Trivett, V., Baker, A.J.M., Aguiar, C. and Pollard, A.J. (2003) Spread of Metals through an Invertebrate Food Chain as Influenced by a Plant That Hyperaccumulates Nickel. Chemoecology, 13, 103-108.

[62] Green, I.D., Diaz, A. and Tibbett, M. (2010) Factors Affecting the Concentration in Seven-Spotted Ladybirds (Coccinella septempunctata L.) of Cd and Zn Transferred through the Food Chain. Environmental Pollution, 158, 135-141. http://dx.doi.org/10.1016/j.sajb.2012.07.013

[63] Cheruiyot, D.J., Boyd, R.S., Coudron, T.A. and Cobine, P. (2013) Biotransfer, Bioaccumulation and Effects of Herbivore Dietary Co, Cu, Ni and Zn on Growth and Development of the Insect Predator Podisus maculiventris (Say) (Hemiptera: Pentatomidae). Journal of Chemical Ecology, 39, 764-772. http://dx.doi.org/10.1007/s10886-013-0289-9 
[64] Sánchez-Chardi, A., López-Fuster, M.J. and Nadal, J. (2007) Bioaccumulation of Lead, Mercury, and Cadmium in the Greater White-Toothed Shrew, Crocidura russula, from the Ebro Delta (NE Spain): Sex- and Age-Dependent Variation. Environmental Pollution, 145, 7-14. http://dx.doi.org/10.1016/j.envpol.2006.02.033

[65] Moriarty, M.M., Koch, I. and Reimer, K.J. (2012) Arsenic Speciation, Distribution and Bioaccessibility in Shrews and Their Food. Archives of Environmental Contamination and Toxicology, 62, 529-538. http://dx.doi.org/10.1007/s00244-011-9715-6

[66] Drouhot, S., Raoul, F., Crini, N., Tougard, C., Prudent, A.S., Druart, C., Rieffel, D., Lambert, J.C., Tête, N., Giraudoux, P. and Scheifler, R. (2014) Responses of Wild Small Mammals to Arsenic Pollution at a Partially Remediated Mining Site in Southern France. Science of the Total Environment, 470-471, 1012-1022. http://dx.doi.org/10.1016/j.scitotenv.2013.10.053

[67] Reglero, M.M., Taggart, M.A., Monsalve-González, L. and Mateo, R. (2009) Heavy Metal Exposure in Large Game from a Lead Mining Area: Effects on Oxidative Stress and Fatty Acid Composition in Liver. Environmental Pollution, 157, 1388-1395. http://dx.doi.org/10.1016/j.envpol.2008.11.036

[68] Chary, N.S., Kamala, C.T. and Raj, D.S.S. (2008) Assessing Risk of Heavy Metals from Consuming Food Grown on Sewage Irrigated Soils and Food Chain Transfer. Ecotoxicology and Environmental Safety, 69, 513-524. http://dx.doi.org/10.1016/j.ecoenv.2007.04.013

[69] Luo, L., Ma, Y., Zhang, S., Wei, D. and Zhu, Y.G. (2009) An Inventory of Trace Element Inputs to Agricultural Soils in China. Journal of Environmental Management, 90, 2524-2530. http://dx.doi.org/10.1016/j.jenvman.2009.01.011

[70] Atafar, Z., Mesdaghinia, A., Nouri, J., Homaee, M., Yunesian, M., Ahmadimoghaddam, M. and Mahvi, A.H. (2010) Effect of Fertilizer Application on Soil Heavy Metal Concentration. Environmental Monitoring and Assessment, 160, 83-89. http://dx.doi.org/10.1007/s10661-008-0659-x

[71] McClellan, K. and Halden, R.U. (2010) Pharmaceuticals and Personal Care Products in Archived US Biosolids from the 2001 EPA National Sewage Sludge Survey. Water Research, 44, 658-668. http://dx.doi.org/10.1016/j.watres.2009.12.032

[72] Jiao, W., Chen, W., Chang, A.C. and Page, A.L. (2012) Environmental Risks of Trace Elements Associated with Long-Term Phosphate Fertilizers Applications: A Review. Environmental Pollution, 168, 44-53. http://dx.doi.org/10.1016/j.envpol.2012.03.052

[73] Fernández-Álvarez, G., Pérez, J. and Gómez, M.A. (2014) Optimization of Reactor Depth in Membrane Bioreactors for Municipal Wastewater Treatment. Journal of Environmental Engineering, 140, 2-22. http://dx.doi.org/10.1061/(ASCE)EE.1943-7870.0000829

[74] Suh, C., Lee, S. and Cho, J. (2013) Investigation of the Effects of Membrane Fouling Control Strategies with the Integrated Membrane Bioreactor Model. Journal of Membrane Science, 429, 268-281. http://dx.doi.org/10.1016/j.memsci.2012.11.042

[75] Environmental Protection Agency (2002) An Gníomhaireacht um Chaomhnú Comhshaoil, European Waste Catalogue and Hazardous Waste List, Valid from 1 January 2002.

[76] Environmental Protection Agency (2011) Definition of Solid Waste Compendium, Volume I: Sludges, § 261.2, 40 CFR Ch. I (7-1-11 Edition) August 2011, Version 2.2, 31-34.

[77] Tian, Y., Zuo, W. and Chen, D. (2011) Crystallization Evolution, Microstructure and Properties of Sewage SludgeBased Glass-Ceramics Prepared by Microwave Heating. Journal of Hazardous Materials, 196, 370-379. http://dx.doi.org/10.1016/j.jhazmat.2011.09.045

[78] Lin, K.L., Chiang, K.Y. and Lin, C.Y. (2005) Hydration Characteristics of Waste Sludge Ash That Is Reused in Eco-Cement Clinkers. Cement and Concrete Research, 35, 1074-1081. http://dx.doi.org/10.1016/j.cemconres.2004.11.014

[79] http://www.yunirisk.com/en/mid/mix/ 